\title{
Statistical Quality Control in Uniformity of Drip Irrigation With Different Slopes
}

\author{
Allan Remor Lopes ${ }^{1}$, Marcio Antonio Vilas Boas ${ }^{1}$, Felix Augusto Pazuch ${ }^{1}$, Luciano Dalla Corte ${ }^{1}$, \\ Diane Aparecida Ostroski ${ }^{1}$, Marcelo Bevilacqua Remor ${ }^{1}$, Fabíola Bogoni Mundstock Mohr ${ }^{2}$, Marcelo Dotto ${ }^{2}$, \\ Alessandro Paggiarin Zanella ${ }^{2}$, Acir Felipe Grolli Carvalho ${ }^{2}$, Alvaro Rodrigo Freddo ${ }^{2}$, Ivan Carlos Bertoldo ${ }^{2}$, \\ Kelli Pirola ${ }^{3} \&$ Camila Moreno Giarola ${ }^{4}$ \\ ${ }^{1}$ Program in Agricultural Engineering, State University of Western Paraná, Cascavel, Brazil \\ ${ }^{2}$ Education Union of South-West Paraná, Dois Vizinhos, Brazil \\ ${ }^{3}$ Federal University of Technology Paraná, Pato Branco, Brazil \\ ${ }^{4}$ Paranaense University, Umuarama, Brazil \\ Correspondence: Allan Remor Lopes, Program in Agricultural Engineeging, State University of Western Paraná, \\ Cascavel, 2069, CEP 85819-110, Bairro Faculdade, Brazil. E-mail: allanremorlopes@gmail.com
}

Received: May 26, 2019

doi:10.5539/jas.v11n16p195
Accepted: July 14, $2019 \quad$ Online Published: September 30, 2019

URL: https://doi.org/10.5539/jas.v11n16p195

\begin{abstract}
The topography directly influences the functioning of an irrigation system, being necessary the determination of the uniformity to verify its performance. Statistical quality control is a powerful tool for verifying the quality of a process. Thus, it was aimed to use the statistical control of quality in the evaluation of the uniformity of a drip irrigation system in different slopes. The Christiansen's uniformity coefficient (UC) and Uniformity of Distribution (UD) were determined and analyzed by the control graphs of Shewhart, Zones and CUSUM and by the indices of process capacity ( $\mathrm{Cp}, \mathrm{Cpl}$ and $\mathrm{Cpk})$, in different slopes $(0 \%, 2 \%$ and $-2 \%)$. The slope irrigation was more uniform $(\mathrm{UC}=99.03 \%$ and $\mathrm{UD}=98.45 \%$ ), however, for all the graphs studied it was out of statistical control. Zone charts were more sensitive than the CUSUM and Shewhart charts.
\end{abstract}

Keywords: microirrigation, control charts, process capability index

\section{Introduction}

Drip irrigation is characterized by the application of water in the form of drops, allowing water to be supplied in small quantities (Resende et al., 2004). The benefits of this method are: Water economy, favors the development of plants, reduction of salinity, possibility of chemigation, limits the development of weeds, reduces labor and energy consumption (Frizzone et al., 2012).

The evaluation of the irrigation system in operation is determined by performance parameters that must be defined based on field determinations, such as flow and application uniformity (Souza et al., 2006).

The performance of an irrigation system is directly proportional to the improvement of crop production variables (Geisenhoff et al., 2015) and minimization of water and energy expenditures (Gris et al., 2015). Distribution uniformity is the main way to determine whether an irrigation system is acceptable or not (Brennan, 2008).

The evaluation of drip irrigation systems in areas with slopes and aclives is necessary due to the variation of pressure in the system, resulting in different flow rates that interfere with distribution uniformity (Lima et al., 2003). The percentage of a localized irrigation system due to declivity can lead to an increase of up to $8.86 \%$ per hectare (Cunha et al., 2014). Souza et al. (2018) concluded that the slope influences the dimensions and geometry of the wet bulb.

Statistical quality control is a tool composed of control charts and statistical process control, which seeks to maintain variables within limits or standards pre-established by technical norms, seeking to ensure that a given process behaves appropriately. For Justi et al. (2010), irrigation systems are perfectly adequate to apply statistical quality control.

Control charts are used to monitor the process and signal to analysts the need to investigate and adjust it according to the size of the deviations found (Walter et al., 2013). 
The process capability indices are used to define how much a process is able to meet the specifications (Tamagi et al., 2016). Silva et al. (2016) point out that process capability indices are tools capable of diagnosing whether the irrigation system has the capacity to remain under control, ie whether it is able to maintain acceptable levels of uniformity.

The study of statistical quality control is already known in the evaluation of the uniformity of irrigation systems. However, their study in drip irrigation systems with different topographic situations is still unknown.

Thus, the objective of this work was to analyze the results of the use of control charts and the index of process capacity in the uniformity of a drip irrigation system in different slopes.

\section{Material and Methods}

The experiment was carried out at the Irrigation and Fertirrigation Laboratory (IFL), at the Experimental Nucleus of Agricultural Engineering (ENAE), at the State University of West Paraná (UNIOESTE), located in the municipality of Cascavel, state of Paraná, Brazil, with Latitude $24^{\circ} 53^{\prime}$ South, Longitude $53^{\circ} 23^{\prime}$ West.

The experiment was carried out with a $5.0 \mathrm{~m}$ long workbench with 4 lateral lines, by means of pulleys, where it is possible to carry out the lateral line, obtaining lateral lines of $10 \mathrm{~m}$ (Figure 1). The bench consists of an Acquapump motor pump (Ferrari), a motor of $0.5 \mathrm{hp}$, maximum flow rate (Q) of $1.8 \mathrm{~m}^{3}$ hour $^{-1}$, maximum manometric head $(\mathrm{Hm})$ of $22 \mathrm{mca}$ and maximum suction of $(\mathrm{Hs})$ of $8 \mathrm{~m}$.

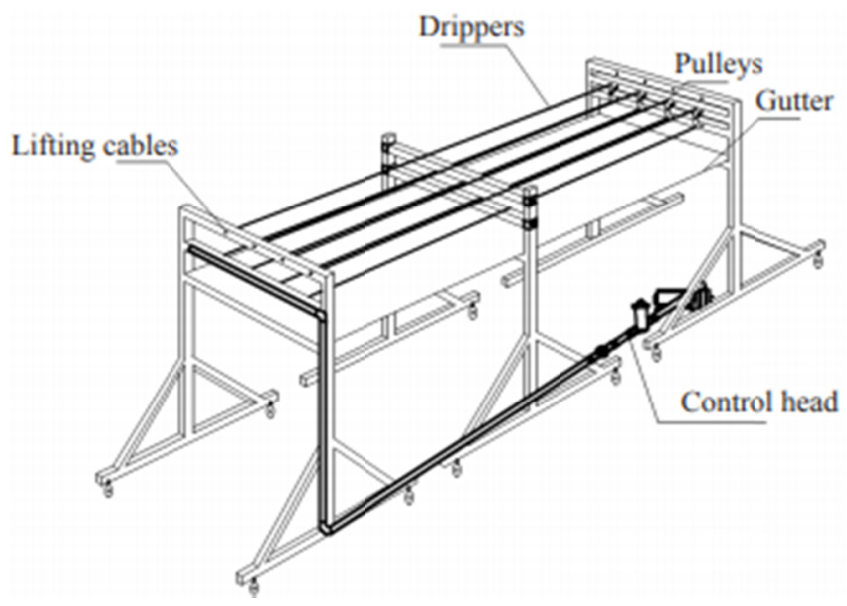

Figure 1. Illustration of the test bench used

The drip tubes tested were of IRRITEC brand, model P1, spaced at $0.5 \mathrm{~m}$, characterized with $16 \mathrm{~mm}$ diameter, maximum working pressure of $80 \mathrm{kPa}$, coefficient of proportionality of the emitter equation (K) of 1.26 and exponent of discharge $(\mathrm{x})$ of 0.48 .

Data collection was performed using the methodology proposed by Keller and Karmeli (1975). This methodology consists in determining the flow rate in 4 emitters per lateral line, that is the first dripper, the drippers located $1 / 3\left(7^{\circ}\right)$ and $2 / 3\left(13^{\circ}\right)$ of the length of the lateral line and the last dripper $\left(20^{\circ}\right)$ in 4 lateral lines.

The flow of the drippers was measured by the gravimetric method, in order to obtain greater precision in the determination. The volume collected in the emitters during 3 minutes, with the aid of plastic collectors, was weighed in a precision scale.

Twenty-five trials were performed for each slope: Aclivity (2\%), Level (0\%) and Declivity (-2\%), this number of samples is recommended by Montgomery (2016) for quality control tests.

From the data of collected flows the Christiansen's uniformity coefficient (UC) proposed by Christiansen (1942) and of the Distribution (UD) proposed by Merrian \& Keller (1978), calculated by equations 1 and 2 respectively, were calculated from the collected flow data.

$$
\begin{gathered}
\mathrm{UC}=\left(1-\frac{\sum_{\mathrm{i}=1}^{\mathrm{n}}|\mathrm{Qi}-\overline{\mathrm{Q}}|}{\mathrm{n} \overline{\mathrm{Q}}}\right) \times 10 \\
\mathrm{UD}=\left(\frac{\mathrm{Q} 25}{\overline{\mathrm{q}}}\right) \times 100
\end{gathered}
$$


Where, $\bar{Q}=$ Arithmetic mean of flows $\left(\mathrm{L} \mathrm{h}^{-1}\right)$; $\mathrm{Qi}=$ flow in the dripper of order $\mathrm{i},\left(\mathrm{L} \mathrm{h}^{-1}\right) ; \mathrm{n}=$ Number of drippers evaluated in the irrigation system; Q25 = Average of $1 / 4$ of the flows with lower values, $\left(\mathrm{L} \mathrm{h}^{-1}\right)$.

To classify the UC and UD data, the following classifications were used, which are described in Table 1.

Table 1. Classification of the Christiansen's Uniformity Coefficient (UC) and Uniform Distribution Coefficient (UD)

Source: Frizonne et al. (2012).

\begin{tabular}{ll}
\hline UC-UD (\%) & Ranking \\
\hline $90 \%$ or greater & Great \\
$80 \%$ to $90 \%$ & Good \\
$70 \%$ to $80 \%$ & Regular \\
$60 \%$ to $70 \%$ & Bad \\
Less than $60 \%$ & Unacceptable \\
\hline
\end{tabular}

In the quality control process, the Shewhart, Zones and CUSUM charts were used.

The Shewhart control chart consists of a center line representing the mean of the desired quality characteristic, an upper control limit line (UCL) and another lower control limit line (LCL) (Frigo et al., 2016 ).

The Zones graph consists of eight zones (four on each side of the center line) (Zhang et al., 2018), bounded by a central line, the limits: 1-sigma, 2-sigma and 3-sigma. Its use is recommended for practical use because of its performance, simplicity, efficiency, ease of use and understanding (Ho \& Case, 1994). For the interpretation of the Zones graphs, the scoring rules (Davis et al., 1990), described in Table 2, were used, and a graph is considered out of statistical control when it reaches 8 points.

Table 2. Scores for each sigma of the zones graph

\begin{tabular}{ll}
\hline Zone & Score \\
\hline Between Central Line and 1-sigma & 1 \\
Between 1 and 2-sigma & 2 \\
Between 2 and 3-sigma & 4 \\
In addition to 3-sigma & 8 \\
\hline
\end{tabular}

Source: Davis et al. (1990).

For the construction of the Shewhart and Zones control charts it was necessary to calculate the upper and lower specification limits obtained by Equations 3 and 4, respectively.

$$
\begin{aligned}
& \mathrm{UCL}=\overline{\mathrm{x}}+3 \frac{\overline{\mathrm{MR}}}{\mathrm{d}_{2}} \\
& \mathrm{LCL}=\overline{\mathrm{x}}-3 \frac{\overline{\mathrm{MR}}}{\mathrm{d}_{2}}
\end{aligned}
$$

Where, $\mathrm{UCL}=$ Upper control limit; $\mathrm{LCL}=$ lower control limit; $\overline{\mathrm{x}}=$ Average of the data; $\overline{\mathrm{MR}}=$ Average of the mobile range of data; $d_{2}=$ Constant when used a moving amplitude of $n=2$ observations $\left(d_{2}=1.128\right)$ (Montgomery, 2016).

In the CUSUM control chart, the deviations from the mean are accumulated over time, generating a cumulative sum obtained according to Equation 5. The CUSUM graph accumulates deviations that are below or above the target value, with statistics $C_{i}^{-}$(CUSUM lower) and $C_{i}^{+}$(upper CUSUM), which are expressed by Equations 5 , 6 and 7.

$$
\begin{gathered}
\mathrm{C}_{\mathrm{i}}=\sum_{\mathrm{j}=1}^{\mathrm{i}}\left(\mathrm{x}_{\mathrm{j}}-\mathrm{u}_{0}\right) \\
\mathrm{C}_{\mathrm{i}}^{-}=\max \left[0 ;\left(\mathrm{u}_{0}+\mathrm{K}\right)-\mathrm{x}_{\mathrm{i}}+\mathrm{C}_{\mathrm{i}-1}^{-}\right] \\
\mathrm{C}_{\mathrm{i}}^{+}=\max \left[0 ; \mathrm{x}_{\mathrm{i}}-\left(\mathrm{u}_{0}+\mathrm{K}\right)+\mathrm{C}_{\mathrm{i}-1}^{+}\right]
\end{gathered}
$$

Where, $x_{j}=$ Average of the $j$ th sample size $n \geq 1 ; C_{i}=$ cumulative sum up to the $i$ th sample; $u_{0}=$ sample mean; $\mathrm{K}=$ compensation value or gap. 
To measure how much the process is able to meet specifications, we use what are called capacity indices. The centered $(\mathrm{Cp})$, lower limit $(\mathrm{Cpl})$ and non centered $(\mathrm{Cpk})$ process indices described in Equations 8, 9 and 10 were used.

$$
\begin{gathered}
\mathrm{Cp}=\frac{\text { USL }- \text { LLS }}{6 \sigma} \\
\mathrm{Cpl}=\frac{\overline{\overline{\mathrm{X}}}-\mathrm{LLS}}{3 \sigma} \\
\mathrm{Cpk}=(\mathrm{Cpl} ; \mathrm{Cp})
\end{gathered}
$$

Where, USL $=$ Upper specification limit; LLS $=$ Lower limit of specification; $\sigma=$ Standard deviation of the data; $\overline{\bar{X}}=$ Average of the data.

Montgomery (2016) classified the process capability indices into recommended minimum values (Table 3).

Table 3. Recommended minimum values of the process capability ratio

\begin{tabular}{lll}
\hline & Unilateral & Bilateral \\
\hline Existing processes & 1.33 & 1.25 \\
New Processes & 1.50 & 1.45 \\
Safety, force or critical parameter (existing) & 1.50 & 1.45 \\
Safety, force or critical parameter (new) & 1.67 & 1.60 \\
\hline
\end{tabular}

Source: Montgomery (2016).

All statistical and graphical analyzes were performed in MINITAB 18 software.

\section{Results}

The data presented in Table 4 represent the physicochemical characteristics of water used in irrigation.

Table 4. Physical-chemical parameters for water used in drip irrigation with different slopes

\begin{tabular}{ll}
\hline Parameters & Results \\
\hline Total iron $\left(\mathrm{mg} \mathrm{L}^{-1}\right)$ & $0.34^{* *}$ \\
Manganese $\left(\mathrm{mg} \mathrm{L}^{-1}\right)$ & $0.050^{*}$ \\
Total dissolved solids $\left(\mathrm{mg} \mathrm{L}^{-1}\right)$ & $60^{*}$ \\
Solids in suspension $\left(\mathrm{mL} \mathrm{L}^{-1}\right)$ & $20^{*}$ \\
Electrical conductivity $\left(\mu \mathrm{S} \mathrm{cm}^{-1}\right)$ & $0.06^{*}$ \\
Sodium $\left(\mathrm{mg} \mathrm{L}^{-1}\right)$ & $2.0^{*}$ \\
$\mathrm{pH}$ & $7.60^{* *}$ \\
Hydrogen Sulfide & $<0.07^{*}$ \\
Calcium $\left(\mathrm{mg} \mathrm{L}^{-1}\right)$ & $2.40^{*}$ \\
Magnesium $\left(\mathrm{mg} \mathrm{L}^{-1}\right)$ & $4.86^{*}$ \\
\hline
\end{tabular}

Note. * Low clogging risk; ** Moderate clogging risk; *** Severe clogging risk.

Source: Nakayama and Bucks (1980); Capra and Scicolone (1998).

Figure 2 shows the system flow maps at level (A), aclivity (B) and declivity (C). 
A

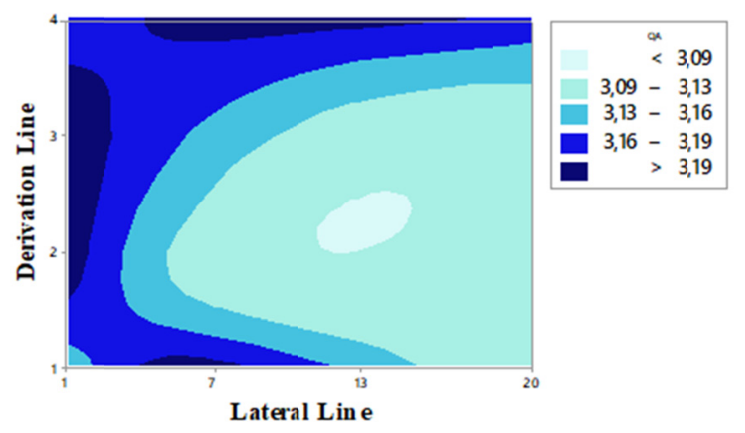

B

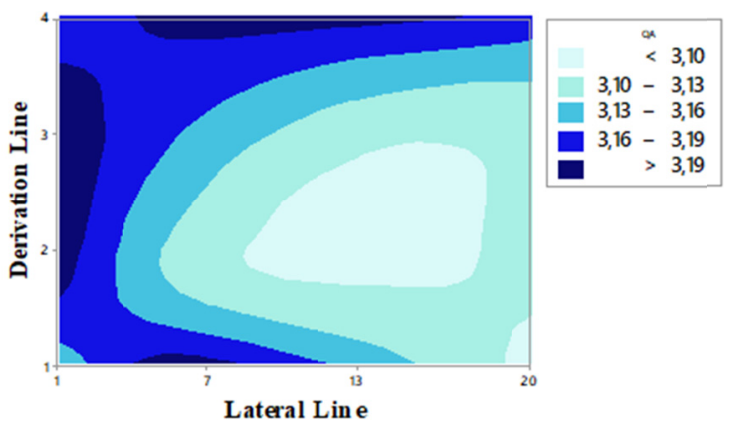

C

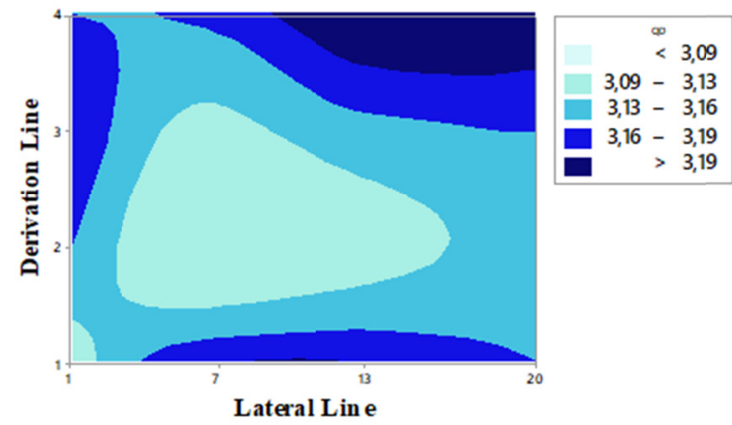

Figure 2. Flow distribution map in: (A) Level, (B) Aclivity and (C) Declivity

Table 5 presents the descriptive statistics for CUC and UD, using the different slopes.

Table 5. Descriptive statistics of the uniformity coefficients UC and UD of the flow of the 25 tests of a drip irrigation system in level, slope and slope

\begin{tabular}{|c|c|c|c|c|c|c|}
\hline \multirow{2}{*}{ Coefficients } & \multicolumn{2}{|c|}{ Level } & \multicolumn{2}{|c|}{ Aclivity } & \multicolumn{2}{|c|}{ Declivity } \\
\hline & $\mathrm{UC}$ & UD & $\mathrm{UC}$ & UD & $\mathrm{UC}$ & UD \\
\hline Minimum & 98.30 & 97.50 & 98.34 & 97.48 & 98.38 & 97.20 \\
\hline Q1 & 98.74 & 97.97 & 98.56 & 97.93 & 99.02 & 98.48 \\
\hline Average & 98.79 & 98.11 & 98.64 & 98.05 & 99.03 & 98.45 \\
\hline Medium & 98.83 & 98.16 & 98.63 & 98.06 & 99.08 & 98.58 \\
\hline Q3 & 98.88 & 98.26 & 98.77 & 98.18 & 99.12 & 98.62 \\
\hline Maximum & 98.87 & 98.45 & 98.87 & 98.56 & 99.22 & 98.72 \\
\hline S. deviation & 0.15 & 0.24 & 0.13 & 0.25 & 0.19 & 0.38 \\
\hline
\end{tabular}

The Shewhart control charts for UC and UD are shown in Figures 3 and 4 respectively. 

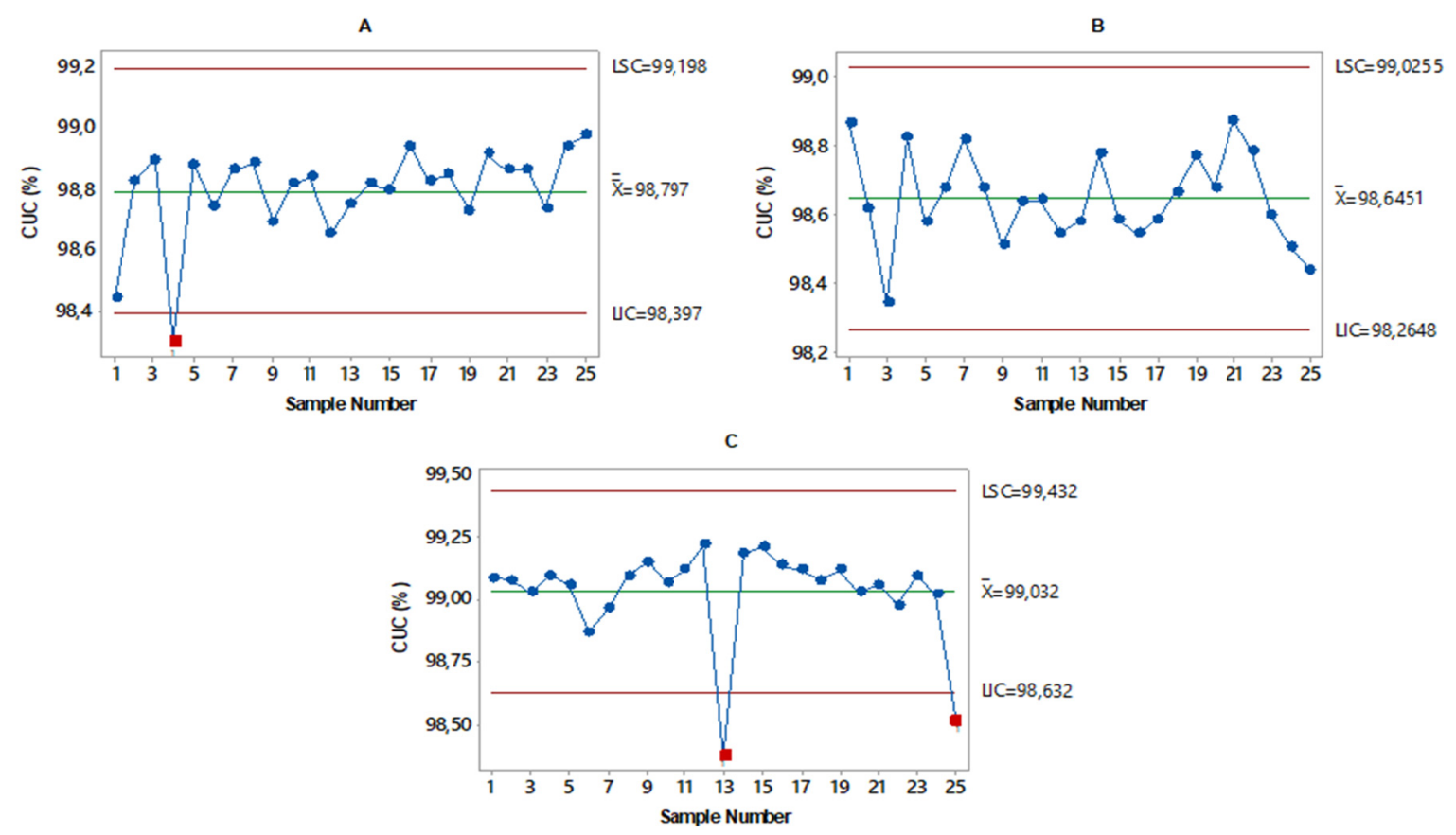

Figure 3. Shewhart control chart for UC in: (A) Level (B) Aclivity (C) Declivity

A

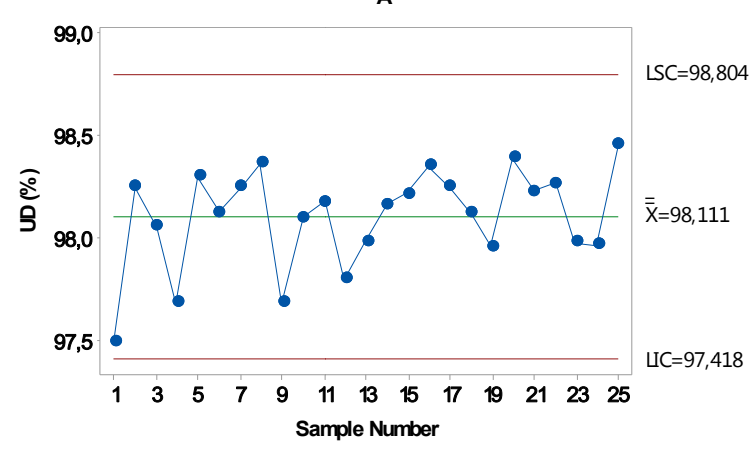

B

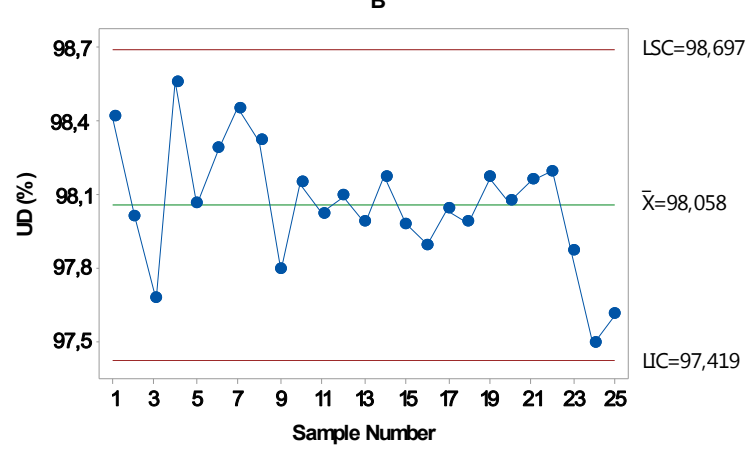

C

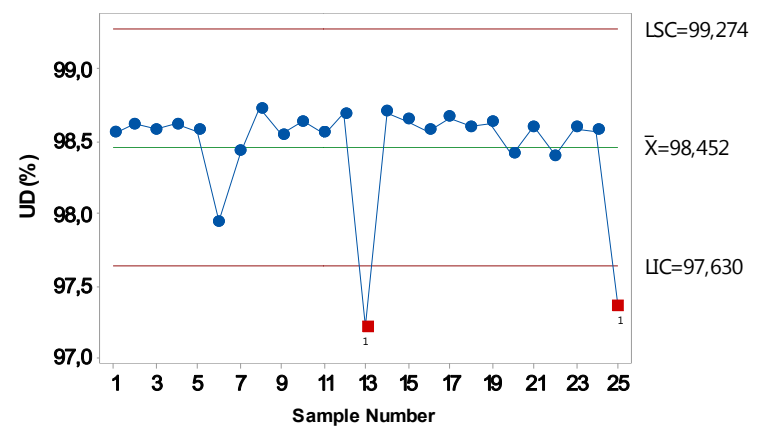

Figure 4. Shewhart control chart for UD in: (A) Level, (B) Aclivity (C) Declivity

The control charts of Zones for UC and UD are shown in Figures 5 and 6, respectively. 
A

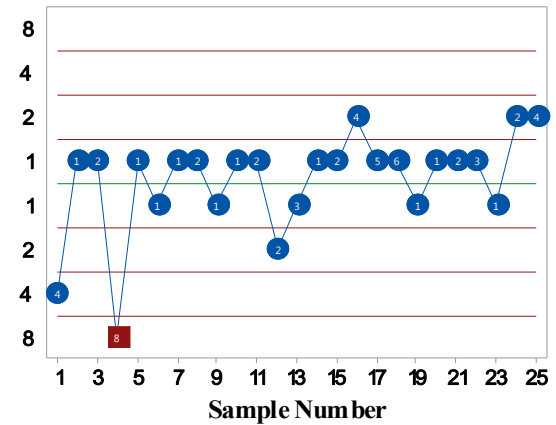

+3 DesvPad=99, 1976

+2 DesvPad=99,0641

+1 DesvPad $=98,9306$

$\overline{\bar{X}}=98,7971$

-1 DesvPad=98,6636

-2 DesvPad $=98,5301$

-3 DesvPad $=98,3967$

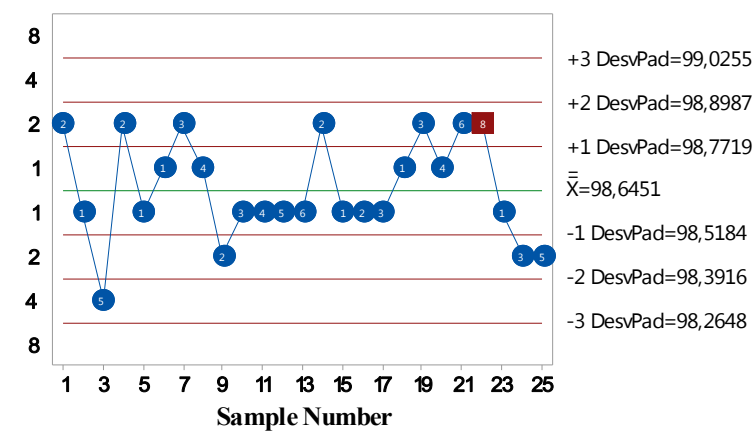

C

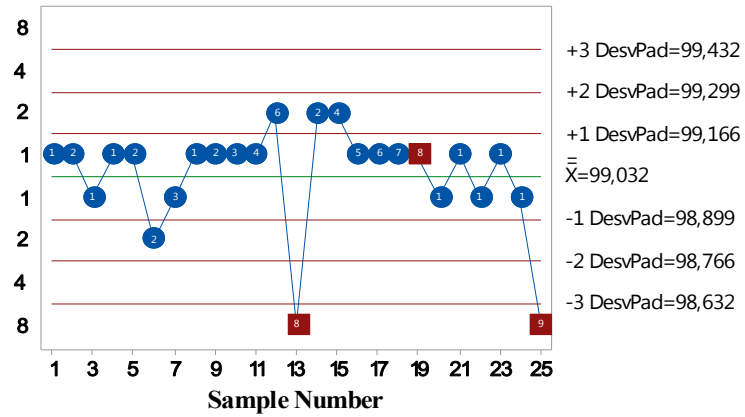

Figure 5. Zone control charts for UC: (A) Level, (B) Aclitivity and (C) Declivity

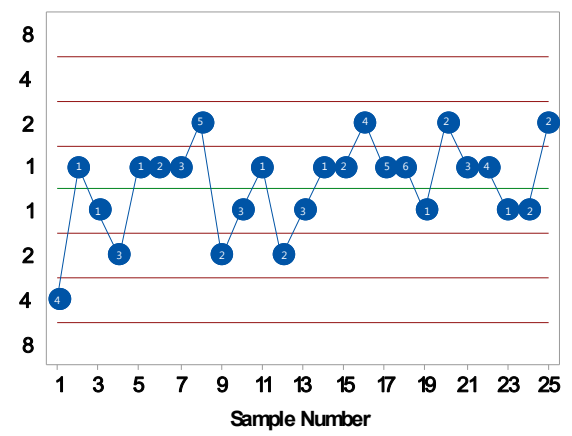

$B$ +3 DesvPad $=98,804$
+2 DesvPad=98,573
+1 DesvPad=98,342 $\overline{\bar{X}}=98,111$ -1 DesvPad $=97,880$ -2 DesvPad=97,649 -3 DesvPad $=97,418$

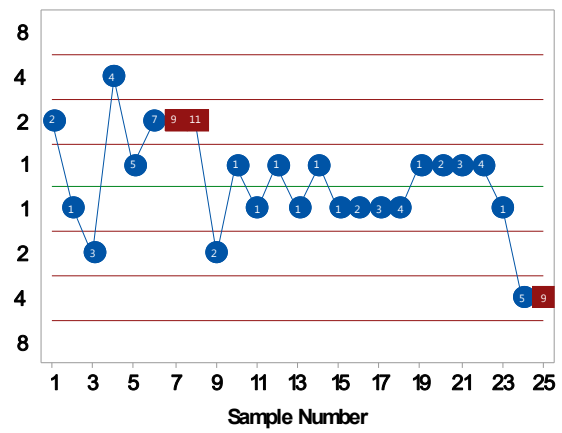
+3 DesvPad $=98,697$ +2 DesvPad $=98,484$ +1 DesvPad=98,271 $\overline{\bar{X}}=98,058$ -1 DesvPad $=97,845$ -2 DesvPad $=97,632$ -3 DesvPad=97,419

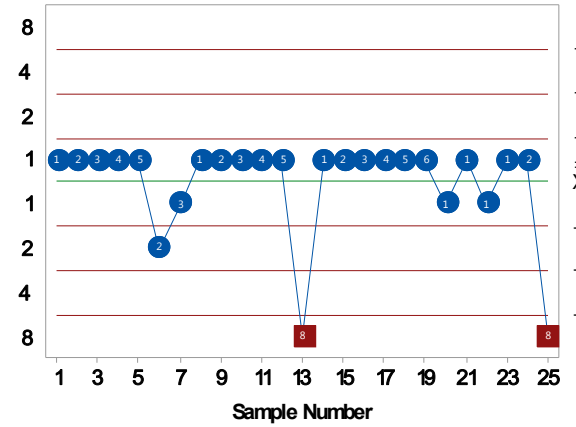

+3 DesvPad=99,274

+2 DesvPad $=99,000$

+1 DesvPad $=98,726$ $\overline{\bar{X}}=98,452$

-1 DesvPad $=98,178$

-2 DesvPad $=97,904$

-3 DesvPad $=97,630$

Figure 6. Zone control charts for UD: (A) Level, (B) Aclivity and (C) Declivity

The CUSUM control charts for the UC and UD are shown in Figures 7 and 8, respectively. 

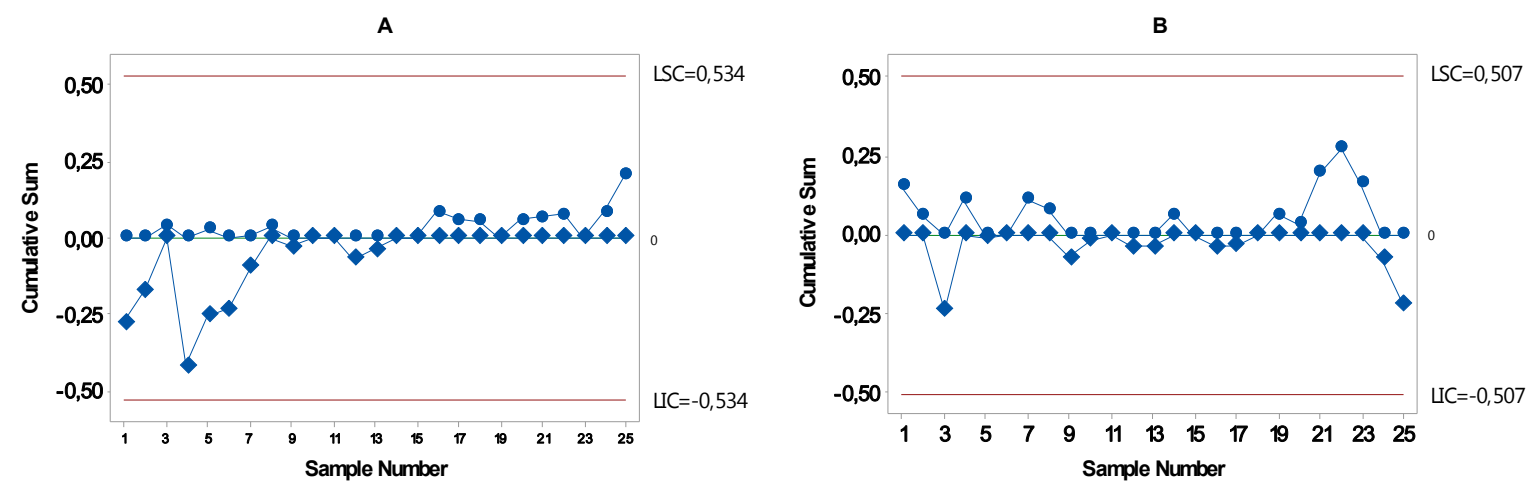

c

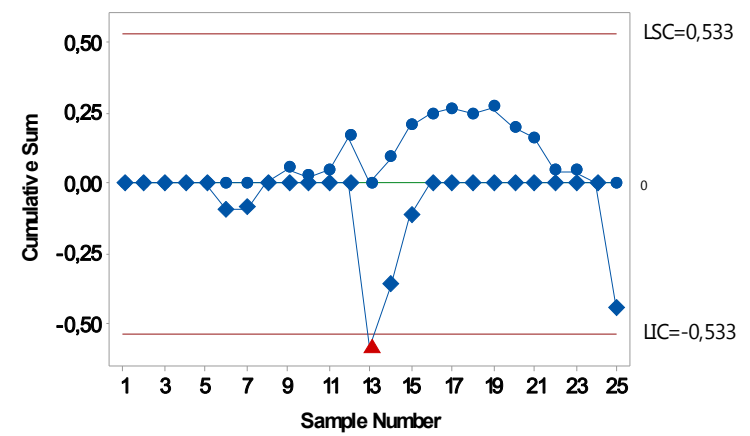

Figure 7. CUSUM charts for UC: (A) Level, (B) Aclivity and (C) Declivity

A

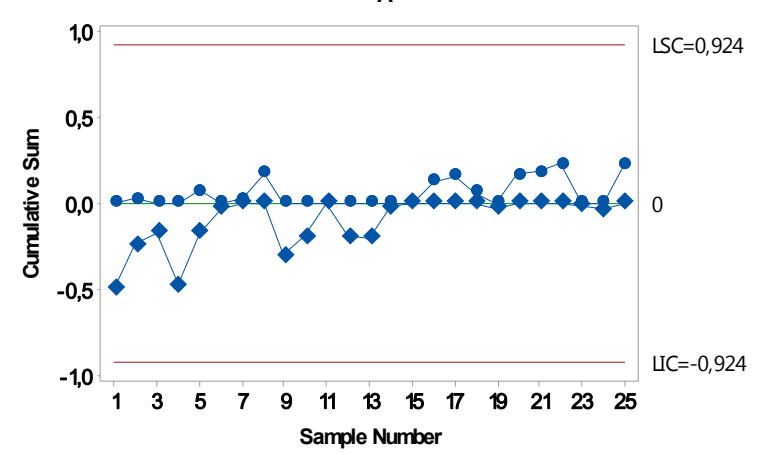

B

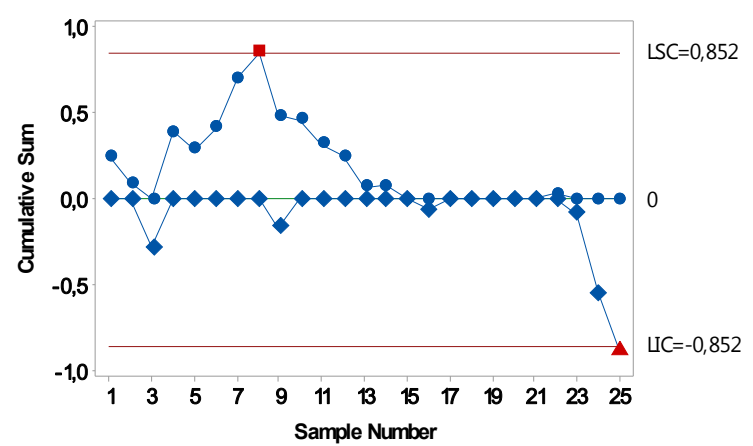

C

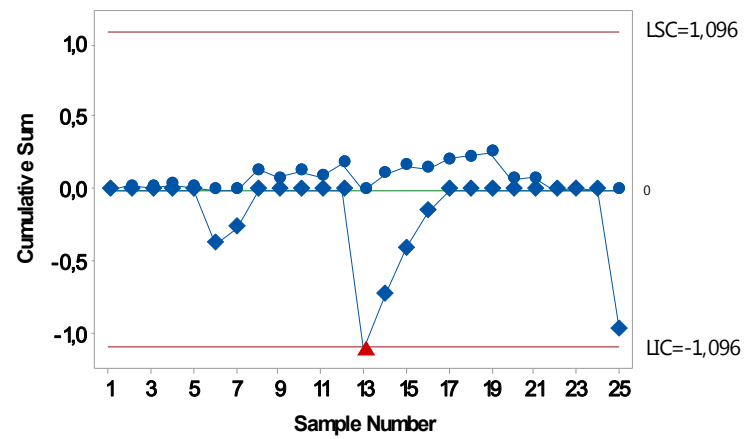

Figure 8. CUSUM graphs for UD: (A) Level, (B) Aclivity and (C) Declivity

Table 6 contains the process capability indices for UC and UD, at different slopes. 
Table 6. Values of process capacity indices (Cp) and process performance (Cpk) for UC and CUD in level, slope and slope

\begin{tabular}{|c|c|c|c|c|}
\hline Coefficient & Level & Índex Cp & Índex Cpk & Índex Cpl \\
\hline \multirow{3}{*}{ UC } & Aclive & 12.48 & 3.00 & 21.97 \\
\hline & Slope & 13.15 & 3.56 & 22.73 \\
\hline & Level & 12.50 & 2.42 & 22.58 \\
\hline \multirow{3}{*}{ UD } & Aclive & 7.21 & 2.73 & 11.70 \\
\hline & Slope & 7.83 & 3.04 & 12.61 \\
\hline & Level & 6.08 & 1.88 & 10.28 \\
\hline
\end{tabular}

\section{Discussion}

The physical-chemical analysis of the water (Table 4) didn't present any parameters with a severe risk of clogging according to the Nakayama and Bucks indexes (1980), and Capra and Scicolone (1998). Only the concentrations of total iron and $\mathrm{pH}$ had a moderate risk of clogging and the other parameters having a low risk of clogging.

According to the contour map (Figure 2), a similar behavior is observed in the system in level and aclivity, with the larger flows at the beginning of the lines and decrease until the end of them. Alves et al. (2015) report that the flow decreases due to the pressure drop during the stretch. For the sloping system, a concentration of the largest flows at the end of the last line was explained by the gradual increase of the pressure that occurs until the end of the pipe (Marcuzzo \& Wendland, 2011).

The average uniformity (Table 5) was excellent for all situations ( $>90 \%)$. The declivity system showed higher excellence in relation to the others, with a higher average uniformity for CUC $(99.03 \%)$ and for UD $(98.45 \%)$. Ella et al. (2009), when studying the uniformity of water distribution in a low-cost drip irrigation system with different slopes and hydraulic loads, verified that uniformity decreased as the slopes increased.

In the Shewhart chart for the UC (Figure 3), it is observed that the level and declivity system were outside the control limits. The level system showed a point outside the control limits. The declivity system presented two points outside the control limits, however, the aclivity system was under statistical control. Pressure destabilization can lead to a point outside the control limits (Silva et al., 2015).

The comparison of UC and UD in the Shewhart chart (Figure 4) shows a different behavior, and the level system was under statistical control. The Shewhart control chart proved to be a good statistical tool in the study of conventional sprinkler irrigation, demonstrating very well the process variability (Frigo et al., 2016).

The control chart of Zones presents high sensitivity, as shown in figure 5 . The UC presents all slopes $(0 \%, 2 \%$ and $-2 \%$ ) outside the statistical control. The level and aclivity system obtained a point out of control, while the declivity system obtained 3 points out of statistical control. Davis and Krehbiel (2002), when comparing the performance of the Shewhart and Zonas control charts, concluded that the zone chart is slightly better at detecting processes that take linear changes over time.

Exploring the UD data in the Zones control chart (Figure 6), it was verified that the level system remained under statistical control by the Zones control chart, while the slopes in aclivity and declivity were out of statistical control. Thus, aclivity, got 3 points and declivity 2 points out of control. Isolated points may be the result of fluctuations in pressure, operator fatigue, some equipment variable or climatic variations (Justi \& Saizaki, 2015).

The CUSUM graph with the UC data (Figure 7) at the level was presented under statistical control, differing from the Shewhart and Zone graphs, which were out of statistical control.

Table 6 shows that the process capacity indices for UC and UD coefficients in all slopes were higher than the established limits $(>1.33)$, that is, they were statistically capable. Silva et al. (2015) also obtained capacity indices above the required limit in drip irrigation. Thus, statistical process control is an excellent tool for the quality of the drip irrigation system.

All coefficients and slopes have $\mathrm{Cpk}>\mathrm{Cp}$, this implies that the processes are within specification point and the distribution is centered. Silva et al. (2015) by studying the process capability index in saline water self-compensating emitters and also obtained Cpk $>\mathrm{Cp}$. The results also corroborate with Andrade et al. (2017) who observed an increase in the process capacity index directly proportional to the mean values of UC and UD. 


\section{References}

Alves, E. S., Araújo, L. M., Alves, J. S. D., Santos, J. E. O., \& Zumback, C. R. L. (2015). Geoestatística aplicada à uniformidade de aplicação de água em sistema de irrigação por gotejamento usado e novo. Revista Brasileira de Agricultura Irrigada, 9(3), 127-135. https://doi.org/10.7127/rbai.v9n300298

Andrade, M. G., Vilas Boas, M. A., Siqueira, J. A. C., Sato, M., Dieter, J., Hermes, E., \& Mercante, E. (2017). Uniformity microsprinkler irrigation system using statistical quality control. Ciência Rural, 47(2), 1-7. https://doi.org/10.1590/0103-8478cr20160546

Brennan, D. (2008). Factors affecting the economics benefits of sprinkler uniformity and their implications for irrigation water use. Irrigation Science, 26(2), 109-119. https://doi.org/10.1007/s00271-007-0077-9

Capra, A., \& Scicolone, B. (1998). Water quality and distribution uniformity in drip/trickle irrigation systems. Journal of Agricultural Engineering Research, 70(4), 355-365. https://doi.org/10.1006/jaer.1998.0287

Christiansen, E. J. (1942). Irrigation by sprinkling (1st ed., p. 124). Berkeley, USA.

Cunha, F. N., Silva, N. F., Teixeira, M. B., Ferreira, J. C., Pais, M. S., \& Gomes Filho, R. R. (2012). Influência do declive no custo total de uma rede de irrigação localizada. Revista Brasileira de Agricultura Irrigada, 6(3), 247-258. https://doi.org/10.7127/rbai.v6n300368

Davis, R. B., Homer, A., \& Woodall, W. H. (1990). Performance of the zone control chart. Communications in Statistics-Theory and Methods, 19(5), 1581-1587. https://doi.org/10.1080/03610929008830278

Davis, R. B., \& Krehbiel, T. C. (2002). Shewhart and zone control chart performance under linear trend. Communications in Statistics-Simulation and Computation, 31(1), 91-96. https://doi.org/10.1081/ SAC-9687284

Ella, V. B., Reyes, M. R., \& Yoder, R. (2009). Effect of hydraulic head and slope on water distribution uniformity of a low-cost drip irrigation system. Applied Engineering in Agriculture, 25(3), 349-356. https://doi.org/10.13031/2013.26885

Frigo, J. P., Vilas Boas, M. A., Frigo, J. P., \& Frigo, E. P. (2016). Comparação entre gráficos de controle de Shewhart, CUSUM e MMEP no processo de irrigação por aspersão convencional. Irriga, 1(1), 56-70. https://doi.org/10.15809/irriga.2016v1n01p56-70

Frizzone, J. A., Freitas, P. S. L., Rezende, R., \& Faria, M. A. (2012). Microirrigação: Gotejamento e microaspersão (1st ed., p. 356). Maringá, Brasil.

Geisenhoff, L. O., Oliveira, F. C., Biscaro, G. A., Almeida, A. C. S., \& Schwerz, F. (2015). Produtividade do brócolis-de-cabeça sob diferentes sistemas de irrigação. Engenharia Agrícola, 35(5), 863-874. https://doi.org/10.1590/1809-4430-Eng.Agric.v35n5p863-874/2015

Gris, D. J., Hermes, E., \& Vilas Boas, M. A. (2012). Aplicação de água residuária de processamento de mandioca em sistema de irrigação por gotejamento. Scientia Agraria Paranaensis, 11, 1-9. https://doi.org/ 10.18188/1983-1471/sap.v11nsupp1-9

Ho, C., \& Case, K. E. (1994). An economic design of the zone control chart for jointly monitoring process centering and variation. Computers \& Industrial Engineering, 26(2), 213-221. https://doi.org/10.1016/ 0360-8352(94)90056-6

Justi, A. L., Vilas Boas, M. A., \& Sampaio, S. C. (2010). Índice de capacidade do processo na avaliação da irrigação por aspersão. Engenharia Agrícola, 30(2), 264-270. https://doi.org/10.1590/S0100-69162010000 200008

Justi, A. L., \& Saizaki, P. M. (2015). Desempenho da irrigação e fertirrigação por controle estatístico de qualidade. Engenharia na Agricultura, 25(6), 541-551. https://doi.org/10.13083/1414-3984/reveng.v23n6 p541-551

Keller, J., \& Karmeli, D. (1975). Trickle irrigation design parameters. Transactions of the ASAE, 17, 678-684. https://doi.org/10.13031/2013.36936

Resende, R. S., Coelho, R. D., Leal, M. L. S., \& Mata, S. S. (2004). Susceptibilidade à intrusão radicular de gotejadores convencionais na irrigação subsuperficial da cana-de-açúcar. Irriga, 5(2), 150-165. https://doi.org/10.15809/irriga.2004v9n2p150-165 
Souza, J. A. R., Moreira, D. A., Salomão, L. C., Cunha, F. F., Pedroso, R. S., Silva, E. L., ... Silva Filho, J. F. S. (2018). Wet bulb dimensions associated with different flow and terrain declivity. Agrican Journal of Agricultural Research, 13(9), 425-431. https://doi.org/10.5897/AJAR2015.9941

Souza, L. O. C., Mantonvani, E. C., Soares, A. A., Ramos, M. M., \& Freitas, P. S. L. (2006). Avaliação de sistemas de irrigação por gotejamento, utilizados na cafeicultura. Revista Brasileira de Engenharia Agricola e Ambiental, 10(3), 541-548. https://doi.org/10.1590/S1415-43662006000300002

Walter, O. M. F., Henning, E., Cardoso, M. E., \& Samohyl, R. W. (2013). Aplicação individual e combinada dos gráficos de controle de Shewhart e CUSUM: Uma aplicação no setor metal mecânico. Gestão \& Produção, 20(2), 271-286. https://doi.org/10.1590/S0104-530X2013000200003

Tamagi, J. T., Uribe-Opazo, M. A., Johann, J. A., \& Vilas-Boas, M. A. (2016). Uniformidade de distribuição de água de irrigação por aspersores compensantes e não compensantes em diferentes alturas. Irriga, 21(4), 631-647. https://doi.org/10.15809/irriga.2016v21n4p631-647

\section{Copyrights}

Copyright for this article is retained by the author(s), with first publication rights granted to the journal.

This is an open-access article distributed under the terms and conditions of the Creative Commons Attribution license (http://creativecommons.org/licenses/by/4.0/). 